\title{
NORMS FOR THE PUBLIC REMEMBRANCE OF NONHUMAN ANIMALS
}

\author{
NORMAS PARA A CELEBRAÇÃO PÚBLICA DE ANIMAIS NÃO- \\ HUMANOS
}

\author{
Matthew McLennan* \\ mmclennan@ustpaul.ca
}

\begin{abstract}
This article builds upon Avishai Margalit's distinction between ethical and moral norms of remembrance. While Margalit is limited by his broadly Kantian framework and restricts his arguments to the remembrance of human beings, the author will argue that the resources exist both in his account and in the particularities of Canadian public life to a) account philosophically for what minimal public ethical norms are in place for the remembrance of nonhuman animals, and b) point towards a more robust, properly moral account of nonhuman animal remembrance. The author will take a recent Canadian case study in the public remembrance of nonhuman animals - the 2012 Animals in War Dedication - to show how existing norms are inherently unstable, pointing beyond themselves to a more species-inclusive, properly moral public perspective.
\end{abstract}

Keywords: morality, ethics, memory, remembrance, animals, Margalit.

Sumário. Este artigo baseia-se na distinção feita por Avishai Margalit entre normas éticas e normas morais de celebração. Enquanto Margalit está limitado pelo seu quadro de referência genericamente kantiano e restringe os seus argumentos à celebração dos seres humanos, o autor argumentará que existem recursos, tanto na sua posição quanto nas particularidades da vida pública canadiana, para: a) explicar filosoficamente as normas éticas mínimas que existem para a celebração de animais não-humanos, $e$ b) apontar para uma posição mais sólida e adequadamente moral acerca da celebração de animais não-humanos. $O$ autor usará um estudo de caso canadiano recente sobre a celebração pública de animais não-humanos - a Dedicação de Animais em Guerra de 2012 - para mostrar como as normas existentes são intrinsecamente instáveis, apontando além de si mesmas para uma perspectiva pública mais apropriada e inclusiva em termos de espécies.

Palavras-chave: moralidade, ética, lembranças, celebração, animais, Margalit.

\footnotetext{
* Saint Paul University.
} 


\section{Ethics and Morality of Public Memory}

Avishai Margalit has written compellingly of both an "ethics of memory" and a "morality of memory". His point of departure is a story taken from a Jerusalem local newspaper, in which an army colonel publicly forgot the name of a soldier killed under his command. As Margalit recounts, "There followed a flood of outrage at the officer who did not remember." (Margalit, 2002, p. 19) This minor episode reveals an aspect of public life that is upon reflection both obvious and under-theorized: remembrance must measure up to certain norms which often are largely implicit until they are violated.

This article is an extension of Margalit's discussion. What is at issue is the public remembrance of nonhuman animals, a topic which does not factor into his account. The argument is centered upon a recent Canadian case study which illustrates how current practices and norms of the remembrance of nonhuman animals - an "ethics of public memory," regarding at least some species and classes of nonhuman animal - point beyond themselves to a more robust, species-inclusive "morality of public memory".

It is important at the outset to define our terms. Margalit distinguishes between ethics - our duties based upon "thick" relations to family, community, tribe, etc. - and morality - our duties to humanity as such. (Margalit, 2002, p. 7) Note that while a community is ideally both ethical and moral, these are conceptually as well as practically separable; it is possible to practice "ethics without moral constraints", a condition that Margalit calls "tribalism" and which can take extreme, aggressive forms as evinced by the Nazi regime. (Margalit, 2010, p. 122) It is also possible, as in the case of the scientific community, to stand in a moral but not always ethical relation to one's peers, relating purely through rational discussion and abstract respect. (Margalit, 2002, pp. 145-146)

Within this framework, it is therefore meaningful to speak of distinctly ethical and moral norms guiding what, whom and how we remember. For instance, I might have an ethical duty to visit the grave of my uncle and recount to my children something of his life; kinship is an important value, he played a 
role in my upbringing, and so on. Here it would be a question of proper norms of respect for those who sustained me when I was vulnerable, and to whom I owe a duty of rites and narratives of remembrance. As Margalit puts it, "Memory is the cement that holds thick relations together, and communities of memory are the obvious habitat for thick relations and thus for ethics." (Margalit, 2002, p. 8) On the other hand, I have a moral duty to remember, mark and recount such events as the Holocaust, slavery, the genocide of First Nations in the Americas, and the Rwandan genocide. These were attacks on the very idea of a shared humanity, which I will gloss from Margalit's account as the presumption of the capacity of each human being to radically change his or her life, i.e. to start over, morally speaking. (Margalit, 2007, pp. 72-76) In participating in acts of mourning and remembrance of crimes against humanity, I affirm precisely the human ideal that they sought to undermine or destroy.

Margalit is broadly Kantian in his approach to morality, but for him the source of human superiority is immanent rather than transcendent. Thus he cleaves to a modified form of humanism:

I take humanism ... to consist of two claims and not just one: first, that human beings are the only source of justification for ethics and morality; second, that humans are a sufficient source for the justification of ethics and morality. I agree with the first claim but not with the second: I believe that human beings are the only source of justification but that this source is not sufficient. (Margalit, 2002, pp. 183-184)

In this way, Margalit may be read as a "fallibilist" or perhaps "postmetaphysical" Kantian; he maintains that there is no absolute fulcrum for the justification of human ethics and morality other than the process of justification itself. (See also Putnam, 2004)

Like Kant, Margalit makes indirect room for nonhuman animals. But this means that his limitations regarding nonhuman animals echo Kant's. For Kant, we can speak of indirect but not direct duties to nonhuman animals, since animals are at best only symbols of the human reason which grounds morality. (Kant, 1980, pp. 239-241) Similarly, in Margalit's case we might speak of ethical but not moral norms regarding nonhuman animals since while many of them participate in our communities, none of them participate in a common humanity. They are perhaps, at best, symbols but not bearers of moral agency. He spells this out explicitly: when we speak of respect for nonhuman animals, really we're speaking of self-respect. (Margalit, 2007, p. 65) 
In describing the cruelty and humiliation which combine to make an inhuman i.e. immoral regime, Margalit relates Hitler's command that the plotters against him in 1944 be "hung like cattle"; "Not treating the dead body of the condemned as human dead body is an expression of humiliation." (Margalit, 2010, p. 65) It is not a question of claiming that nonhuman animals, as opposed to human beings, can be treated as mere objects. Rather, the claim is that to treat a human being "like an animal" is inherently immoral. (Margalit, 2007, p. 89) As Margalit puts it: "Morality is the undertaking to regulate human relations between human beings. Human beings should also establish humane relations with animals, but that is a different undertaking." (Margalit, 2010, pp. 140-141) This undertaking would not, by definition, include moral norms of remembrance.

I will repeat that I hold Margalit to take a "broadly", not a strictly, Kantian position. Indeed, he gives an explicit analysis of Kant's norms of human respect that reveal the extent to which he, Margalit, both is and is not a Kantian. (Margalit, 2007, pp. 66-67) The problem here is that, like Kant, Margalit courts risk by grounding the definition of "humanity" in a capacity that is presumably restricted to fully competent adults. Children and those with severe, possibly even moderate, intellectual disabilities are at issue. We might set children aside, to the extent that - all things being equal - they will grow into their moral freedom and therefore already possess it, very loosely speaking, as a "capacity". This move cannot be made for those with irremediable intellectual impairment. At the limit, this would imply that crimes against some human persons who are not moral agents would not technically count as crimes against humanity. Oddly, the Nazi genocide of persons with intellectual disabilities, for example, would be unethical but not immoral on this picture. Subsequently, there would then be an ethical, but not a moral, duty of remembrance of the crime. This is counterintuitive and puts the interests of such persons in a precarious place.

One way to try to escape the problem - assuming that we wish to retain radical moral freedom as the necessary criterion of respect for humanity - would be simply to grant persons with intellectual disability honorary status as moral agents, i.e. an honorary human status. It seems that Margalit is forced to make this move, problematic as it sounds. He claims "the chief premise of morality" to be "the idea that all human beings should be subjected to moral treatment solely 
because they are human." (Margalit, 2010, p. 190) But we have seen that he is precisely not talking about the human species, i.e. human DNA as a source of moral standing; he is referring to moral autonomy. The chief premise of morality is therefore either circular and exclusionary (the moral autonomy of some members of the species homo sapiens commands the moral treatment of morally autonomous members of the species homo sapiens) or it is inclusive but arbitrary (the moral autonomy of some members of the species homo sapiens commands moral treatment for all members of the species homo sapiens). In this connection, Margalit shows awareness of the need to extend his premise in an honorary if arbitrary way when he critiques common social attitudes towards adults with Down syndrome; specifically, he disagrees that they may be treated as perpetual children or as less than fully human. (Margalit, 2007, p. 110) Agreeing with Margalit that persons with Down syndrome should be treated with respect, I differ from him over the basis of this respect. It is not the high level of moral functioning possessed by autonomous, average adult humans but rather something more basic.

This basis for respect or moral standing - sentience, being a "self" - will be further discussed below. For now, note the problem: Margalit's picture is vulnerable to the "argument from species overlap." (Horta, 2014) If human persons who fail to meet the stated criterion for humanity can nonetheless be included under the umbrella of "shared humanity", then there is no obvious reason why at least some species of nonhuman animals cannot also be included. To shift the basis of inclusion to biological species would be to move the goalposts in an arbitrary way.

\section{Case Study: The Animals in War Dedication}

The preceding shows how Margalit's account of ethics and moral norms of remembrance cannot exclude nonhuman animals if it wishes to avoid the charge of arbitrariness. I will now draw upon a Canadian case study to show how the issue is not entirely theoretical. Existing practices in the public remembrance of nonhuman animals are philosophically unstable and, like Margalit's theory, point beyond themselves to more robust, species-inclusive moral public norms. 
On November 3, 2012, the Government of Canada unveiled the Animals in War Dedication in Confederation Park, Ottawa. ${ }^{1}$ According to Veterans Affairs, the Government of Canada contributed "more than \$98,00o" towards the monument's creation and unveiling. ${ }^{2}$

The unveiling ceremony was attended by "Mr. Royal Galipeau, Member of Parliament for Ottawa-Orléans and representative for the Honourable Steven Blaney, Minister of Veterans Affairs, Senator Yonah Martin, Mrs. Laureen Harper, Honorary Patron of the Animals in War Dedication Project, BrigadierGeneral M.K. Overton, Assistant Chief of Military Personnel of the Canadian Armed Forces, and Mr. Russell Mills, Chair of the National Capital Commission (NCC), along with [World War II and Korean War] Veteran Lloyd Swick, founder of the project" The dedication "consists of three interpretative plaques explaining the roles played by animals during past wars. A bronze statue of a medical service dog stands nearby." "The footprints of dogs, horses and mules are stamped into the concrete of the Animals in War Dedication, representing the marks they left on the battlefield." 3 The dog stands loyally near the foot of the South African War Memorial. The placement itself is symbolic, since in the Boer War "Canada supplied 50,000 horses for mounted troops."4

In its news release, Veterans Affairs quotes distinguished participants of the unveiling and briefly describes the role of animals in Canadian military campaigns:

'As a tribute to the efforts of animals who served during crucial battles, we honour their unwavering loyalty, dedicated service, and strong companionship during difficult times' said Minister Blaney. 'With the unveiling of this dedication, Canadians now have a place to honour animals who've served in war alongside our Veterans,' said MP Galipeau. 'Animals have always been a part of our lives and of our culture and should be recognized for their contributions to Canada's war efforts.' 'This dedication in Canada's Capital Region will help Canadians discover the contributions of animals in war,' said Mr. Mills, Chair of the NCC (...) A variety of animals were used during war. Mules carried supplies and artillery; horses hauled field guns; carrier pigeons delivered messages to specific destinations; and dogs

\footnotetext{
${ }^{1}$ See the official website of the monument at http://aiwdedication.ca/ (accessed Feb.12, 2013).

${ }^{2}$ http://www.veterans.gc.ca/eng/department/press/viewrelease/1610 (accessed Feb.12, 2013).

${ }^{3}$ http://canada.pch.gc.ca/eng/1443025436013 (accessed August 16, 2016)

4 http://canada.pch.gc.ca/eng/1443025436013 (accessed August 16, 2016)
} 
worked as messengers, medical assistants, mine detectors and in search and rescue. Dogs are still employed by the Canadian Armed Forces today. 5

The Animals in War Dedication is not the first of its kind in Canada; the Tympanum of the Peace Tower on Parliament Hill "represents the animals that served during the [First World] war: reindeer, pack mules, carrier pigeons, horses, dogs, canaries and mice", and bears the inscription: "THE TUNNELLERS' FRIENDS, THE HUMBLE BEASTS THAT SERVED AND DIED."6 Similar monuments may be found abroad, for example Britain's Animals in War Memorial.7

That the monument is of philosophical interest is evident in the language surrounding its unveiling. Unlike their human counterparts, military service animals were "used" for specific purposes; in other words they are considered to be objects, or means to an end. Yet the animals honoured also "worked" at particular jobs; they are thus considered to be labourers, subjects, and, arguably, ends in themselves. The troubled language surrounding the unveiling speaks to a deep philosophical tension.

I do not in the least critique the admirable motives of project founder Lloyd Swick, but rather mount a philosophical criticism based on the clash between what the monument appears to be communicating on one hand, and the policies and practices of the government which erected it on the other. Orienting my argument around Peter Singer's classic utilitarian defence of animals, as well as Sue Donaldson and Will Kymlicka's 2011 study Zoopolis: A Political Theory of Animal Rights, I will suggest that the Canadian government's gesture of recognizing the contributions and sacrifices of some species of nonhuman animals is suggestive of a political philosophy that it simply does not believe in, and policies it does not advocate. Were it not for the fact that it continues to support the military use of some nonhuman animals in particular, and existing systems of animal exploitation more generally, the Government of Canada's erection of the Animals in War Dedication would bear an altogether different and more straightforward meaning.

\footnotetext{
${ }^{5}$ http://aiwdedication.ca/ (accessed Feb.12, 2013).

${ }^{6}$ http://www.parl.gc.ca/About/House/Collections/heritage_spaces/memorial/stone/3369-e.htm (accessed Sept. 16, 2016)

${ }^{7}$ http://www.animalsinwar.org.uk/ (accessed August 16, 2016)
} 
Giving a version of the aforementioned "argument from species overlap" I will show, first, that if we do not want to exclude certain classes of human beings, then we must accord equal moral standing to nonhuman animals. This furnishes grounds for a critique of the government's unveiling of the new monument, as I will explain. Next, I will question whether and to what extent animals should have differentiated political rights, noting that the new monument treats nonhuman animals as citizens; this too furnishes grounds for a critique of the government's gesture. I conclude this section by suggesting that the adoption by the Government of Canada of a robust account of animal moral standing and/or political rights would be a necessary condition to removing the contradiction implied by its unveiling the monument. For the Animals in War Dedication to truly honour nonhuman animals in war, the Government of Canada would need to radically alter both its moral and political conception of nonhuman animals, as well as its policy of using some animals for military purposes to this day, as I will describe.

To have "moral standing" is to count in moral deliberations. "Do nonhuman animals count, morally speaking?" is a question that has been debated extensively in academic literature. But it is generally recognized, both within and without the academy, that there should be at least some moral and legal limits to the human exploitation of nonhuman animals. There are major philosophical disagreements as to the specific reasons for which these limits should be drawn, and there are likewise palpable differences over their practical implications. I cannot hope to do justice here to the range of theoretical options pertinent to these questions. For the purposes of the following, however, the discussion will roughly distinguish between consequentialist and rights positions (noting in passing that options such as contractarian, care and capabilities approaches trouble this distinction). Consequentialists make the comparatively modest claim that nonhuman animals have moral standing, i.e. that we should count their interests when we deliberate, and that what happens to them matters, morally speaking. Those arguing from a rights position go further and claim that there are inviolable moral limits to our dealings with nonhuman animals (i.e. they have moral rights in the strict sense). 
Recognizing nonhuman animal moral standing is not necessarily tantamount to recognizing species equality. Many people devote considerable yet rather selective efforts to animal welfare. For example, Laureen and Stephen Harper publically supported the Ottawa Humane Society's Foster Program, pleading on the Prime Minister's website for the care and humane treatment of cats and dogs. But Prime Minister Harper's tweet from December 21, 2012 underscores the selectiveness of his commitment to animal welfare. He tweets “@HomerJSimpson Mmm... bacon” and we are treated to a clip from The Simpsons in which several characters taunt a vegetarian (singing "you don't win friends with salad").8 The political gaff of tweeting about the enjoyment of food during First Nations Chief Theresa Spence's hunger strike should of course be noted, but for our purposes the PM's tweet is interesting in that it communicates very clearly that there will be no special pleading for pigs.

Peter Singer's classic consequentialist account argues convincingly, however, that "all animals are equal" (Singer, 2010); that is to say, that they have equal moral standing. Humans, pigs, dogs, cats, birds and all roughly comparable organisms are to count equally in moral deliberation. The reason for this is simple; all such beings have the capacity to suffer, and therefore have an equal stake in the avoidance of suffering. It may seem that Singer has set the bar for moral standing excessively low, but his reasons are compelling. If the basis for moral standing were something like reason, linguistic ability or, as we saw with Margalit, moral agency, then we would have to exclude a wide swath of humanity from (direct) moral standing. Many human beings are so intellectually disabled that they will never possess these qualities. In some cases - acknowledging both the risk of ableism attendant to this move, as well as the conceptual difficulties of comparing cognition across species (Taylor, 2017; De Waal, 2016) - nonhuman animals could be argued to cognitively outrank them.

The existence of certain atypical (often called "marginal") human cases has in any case long troubled those critics of Singer who would maintain the moral inequality of species. We could by fiat claim that membership in the species homo sapiens puts the severely intellectually disabled above animals, morally speaking.

${ }^{8}$ https://twitter.com/stephenharper/status/282233267623714816?lang=en (accessed October 6, 2017) 
But then this would be a case of moral preference based on an arbitrarily selected and apparently morally irrelevant factual criterion. We might as well restrict moral standing to sex, or race, or physical strength. Indeed, Singer claims that wherever we are prepared to treat sentient beings differently based on species membership, this is "speciesism", by analogy with sexism and racism. (Singer, 2010, pp. 569-571) No qualitatively richer, typically human capacity, such as reason or the ability to communicate or to be moral agents, puts us above nonhuman animals - unless we are prepared to be ableist (deny moral standing to humans who lack such intellectual capacities). Getting around this problem by granting special inclusion to the intellectually disabled is, to repeat, speciesist and therefore philosophically and morally indefensible; in short, an intellectually honest account of moral standing sufficiently broad to include severely intellectually disabled humans would also have to include nonhuman animals, irrespective of species. Were Prime Minister Harper consistent in his animal welfarism he would plead for pigs as well as for cats and dogs.

Note however that recognizing the equal moral standing of nonhuman animals is not the same thing as recognizing their rights. Being a utilitarian, Singer does not believe in moral rights at all. Though he typically rejects arguments in defense of nonhuman animal exploitation, he is prepared to grant that there could be times when exploiting nonhuman animals (or humans) serves aggregate utility and is therefore acceptable. He is even prepared to make allowances for eating nonhuman animal proteins. For example, there is no moral presumption in favour of a vegan diet in much of the global South, where people lack readily available alternative sources of vitamin B12. (Singer \& Mason, 2006, pp. 226-237) Similarly, it might be argued that there would be no such presumption on the part of Canada's First Nations. But where protein alternatives and supplements are within reach of urban settler populations, many people of average health would appear to face a utilitarian presumption against nonhuman animal exploitation for dietary reasons.

How then does all this shed light on the Animals in War Dedication? As MP Galipeau puts it, the monument is erected in the spirit that nonhuman animals "should be recognized" for their contributions and, by extension, their sacrifices. Indeed, one of the plaques on the dedication describes how many horses in WWI 
"paid the ultimate price" for their contributions. This betrays recognition of their interests, and such recognition, if intellectually honest, automatically grants them moral standing. But note two things. First, recognition of moral standing is not tantamount to recognition of equal moral standing, as we saw in the case of the selective animal welfarism of the Prime Minister. In erecting the monument, the Government of Canada is praising the contributions of some animals while continuing to legally allow and even subsidize the exploitation and deaths of countless others. But speciesism is, to repeat, philosophically indefensible. In this light, the Dedication may be read as a sentimental yet arbitrary gesture.

Second, consequentialist views such as Singer's are, in principle, perfectly compatible with sending nonhuman animals to war if doing so contributes to aggregate utility. It would appear then that from a rigorously egalitarian consequentialist approach to nonhuman animals, there is nothing amiss with the monument. But bear in mind the following consideration. Canada does not practice conscription of human military personnel. Military service for human beings is, in principle, a free choice. Since nonhuman animals cannot understand the nature of military service and therefore cannot consent to it, their participation is not similarly free. The government thus by definition conscripts animal personnel and as such it makes special allowances for conscription based on species membership. Here we could cite the argument that nonhuman animals lack the capacities of normal adult Canadians and therefore may be conscripted without moral compunction. We could also argue that in some cases, as with explosive-detecting dogs, the deployment of nonhuman animals directly saves human lives.

But note that we do not and would not conscript intellectually disabled humans to military service on these same grounds (indeed, in principle they would be screened out of the application procedure). Imagine a genetic disorder that renders a human being severely cognitively disabled and incapable of managing her own affairs, but imbues her with heightened ability to detect mines and explosives. No self-respecting nation would send her into service on the grounds of her usefulness, and any proposals to that effect would be rightly condemned. We would and do, however, send a dog with comparable capacities to perform such tasks with little hesitation. Considering that a comparable 
monument thanking conscripted, severely intellectually disabled human beings for their contributions to military campaigns would rightly be judged an obscenity, the erection of the Animals in War Dedication bespeaks our country's speciesism and is on these grounds open to criticism.

Consider further the military use of children. The practice is widely condemned because children cannot consent to serve in war by virtue of what is recognized, both in law and in moral theory, to be their diminished autonomy and capacity for moral agency. Since in children this lack of autonomy is not considered to give guardians the right to send them to war, by parity we could argue that intellectual disability and the inbuilt cognitive limitations (from a human point of view - See De Waal, 2016) of nonhuman animals do not likewise count in favour of their conscription. Naturally, a "children in war" monument that did not criticize the military exploitation of children could fairly be called an atrocity added to an atrocity. But it might be objected that statistically normal children possess the potential to become fully autonomous adults; perhaps what is so wrong about their deployment in war is the way in which it irrevocably scars them and thwarts their attainment of future goods. Valuing potential in this way however would be no reason to disallow child conscription on the one hand, and practice animal conscription on the other, since to repeat, many intellectually disabled humans lack the potential of children. Such a policy is caught in a dilemma: either we support ableism (potential autonomy is the criterion for moral consideration) or we support speciesism (being human is the criterion for moral consideration).

In sum, the belief in animal welfare as a morally important goal raises the broader question of the basis of moral standing. If we wish to be sufficiently inclusive in our criteria for moral standing that we do not leave out intellectually disabled human beings, while avoiding the philosophically indefensible move of speciesism, then we need to set the bar such that nonhuman animals are put morally on par with humans. This being so, the Animals in War Dedication is problematic because in the same way that an uncritical dedication to conscripted, intellectually disabled humans or children would be. Had the monument been unveiled to memorialize beings mistreated in the past as the result of benighted policies, then things would of course be different. But there is no such indication 
on the part of the Government of Canada, which admits without hesitation or regret that dogs are still deployed in military operations.

Animal Rights Theory or ART would point us to similar conclusions while differing importantly from consequentialist accounts like Singer's. As the name would suggest, such a theory envisions full moral rights for nonhuman animals, in the sense of there being inviolable moral boundaries in our dealings with them. On Donaldson and Kymlicka's view these rights are generated by the possession of selfhood, which is a precondition for having interests. Here again, the criterion for rights is fixed widely enough to protect intellectually disabled human beings, and barring a speciesist exception, this entails comparable basic rights for animals.

Bracketing for sake of argument the philosophical defensibility of rights, there is a good deal to recommend ART over Singer's position. Above, I discussed the protection of the severely intellectually disabled as a matter of hypotheticals: philosophically speaking, if we want to protect the interests of such humans, then we are compelled to protect those of nonhuman animals as well. But from certain consequentialist positions (for example act utilitarianism) it is always, in principle, possible to make exceptions to the protection of such interests. Some consequentialists, such as R.G. Frey, simply "bite the bullet" (Donaldson \& Kymlicka, 2011, p. 28) when it comes to atypical or "marginal" human cases, suggesting for example that if utilitarian arguments in favour of animal testing hold water, then we must be open to testing on intellectually disabled humans as well (in fact, there is according to this view an utilitarian presumption in favour of human testing over animal testing, since human models will give us more scientifically accurate and practically useful information) (Frey \& Paton, 2010). In response to this kind of reasoning, many philosophers have tried to hammer out a convincing account of inviolable human rights. But in casting their account wide enough to protect intellectually disabled humans, such rights automatically entail animal rights. A representative but clumsy critique of ART which tries to get around this implication comes from Michael Allan Fox (2006), who insists that the very notion of a right implies corresponding duties (i.e. on the part rightsbearers). This of course generates the troubling implication that severely 
intellectually disabled humans lack rights, which Fox denies by making a philosophically indefensible speciesist exception.

So much for inviolable moral boundaries, i.e. negative rights. The Animals in War Dedication is also interesting because it puts the question of nonhuman animal positive political rights - that is to say, citizenship - on the agenda. Reading the Animals in War Dedication charitably, it is a gesture of gratitude and praise to such animals for defending Canadian sovereignty. If we can thank such beings for their participation in some aspect of political sovereignty, then we can at least meaningfully pose the question of their political status with regard to Canada as a sovereign nation.

This is where Donaldson and Kymlicka's recent intervention in animal ethics proves helpful. They make the admittedly controversial point that because of its focus on inviolable negative rights for nonhuman animals, classical ART generally envisions animal ethics as an ethics of non-interference. (Donaldson and Kymlicka, 2011, p. 9) The Animals in War Dedication could in this light be criticized on the grounds that it sentimentalizes a case par excellence of interference with nonhuman animals. But Donaldson and Kymlicka point out that its focus on negative inviolable rights renders the classical rights position insufficiently nuanced, to the point of being counterproductive. It does not, for example, make allowances for the fact that humans and nonhuman animals may engage in mutually beneficial and satisfying cooperative relationships. To this extent, animals such as dogs and horses killed in war should indeed be mourned as lost friends and social collaborators. An ethic of non-interference may indeed be the right approach as far as wild and opportunistic/liminal animals are concerned, as Donaldson and Kymlicka argue in their sixth chapter (though this is highly contentious; see Mannino, 2015 and Faria, 2016). Such an ethic would ignore however the rather intuitive claim that as humans we may have positive duties to species we have domesticated on account of our having rendered them, through breeding, incapable of survival in the wild. Not withstanding what may be plausibly argued to have been the initial injustice of domestication, the existence of domesticated nonhuman animals generates positive duties on our part with respect to them. In other words, we do not remedy the injustice of domestication by abandoning the animals we have already domesticated. 
We must bear in mind what, precisely, is entailed by this positive notion of animal rights. Donaldson and Kymlicka do not advocate for animals to have the right to vote, or any such nonsense; rather, in the same way that severely intellectually disabled humans may be considered citizens but minors or wards of state, domesticated animals should be granted citizenship rights entailing no duties on their part, but specific duties on the parts of human institutions and caregivers. As Donaldson and Kymlicka point out, political agency is only one aspect of citizenship, which also includes national identification and popular sovereignty (2011, pp. 55-61). If domesticated nonhuman animals are excluded from citizenship on the basis of their incapacity for political agency, then surely (barring indefensible speciesism) we would have to similarly exclude infants, children, the intellectually disabled, the temporarily unconscious, and those with dementia. Though admittedly counterintuitive, the claim that domesticated nonhuman animals are entitled to citizenship rights holds water for the reason that its denial renders citizenship an unacceptably fragile and exclusionary matter in the case of humans.

Let us ask, then, if the provisional admission of domesticated nonhuman animal citizenship implies the permissibility of such animals being sent to war, or even a duty on their part to serve Canadian military interests. We may dispose of the possibility that such animals have a duty to protect Canadian sovereignty. Since Canada "lags woefully behind" other industrialized nations "regarding even the most minimal reforms" of animal welfare (Donaldson \& Kymlicka, 2011, p. 259), it is not evident that domesticated nonhuman animals have a duty to defend (nor any particular stake in) Canadian sovereignty; the claim that they do smacks of the rather repugnant claim that human slaves are duty bound to defend the political territories of their masters. But even if Canada were to become a world leader in progressive animal policies, this would still not generate the duty for nonhuman animals to serve - unless of course we were prepared to admit that progressive disability policies for humans generate a comparable duty on the part of humans who would thereby benefit. As to whether or not it is at least morally permissible to send such (provisional) nonhuman citizens to war, here again parity with the case of intellectually disabled humans rules out an affirmative answer. 
The Animals in War Dedication, as conceived by Lloyd Swick, is therefore laudable to the extent that it treats nonhuman animals a) as if they have moral standing, however we cash that out, and b) as if they are citizens. But these very laudable recognitions also prove that the gesture of the Government of Canada behind the monument is philosophically confused, and morally problematic. In essence, the monument does not go far enough in its recognition of nonhuman animals.

Summing up the argument of this section, nonhuman animals do indeed have moral standing, by virtue of their capacity to suffer and have interests. The monument recognizes this. But if we adhere to a consistent and intellectually honest animal welfare framework, the speciesism of the monument also immediately becomes apparent. By erecting the monument in light of existing laws and policies the Government of Canada is doing two things: first, betraying a belief that some animals should be arbitrarily singled out for praise, while others unceremoniously exploited, killed, and eaten; second, symbolically thanking and praising creatures with interests of their own for contributions and sacrifices that we would never demand of cognitively comparable members of our own species. The monument is philosophically and politically indefensible by reason of a) its arbitrariness and b) its support of inexcusably exploitative practices.

As to the much more novel question of whether nonhuman domesticated animals should have citizenship rights, the language of the press release surrounding the monument certainly seems to imply it. It errs not in treating domesticated animals as Canadian citizens so much as in treating them as fully autonomous political agents, capable of consenting to go to war. Considering, once again, that we could never justify sending our severely cognitively disabled or our children to war for the reason that they count as citizens to whom we owe special duties of care and protection, the monument makes a grave philosophical and political mistake. It normalizes gratitude to beings that cannot fully understand the nature of the actions for which they are thanked, and that for this reason cannot consent to them in the first place.

Were the Government of Canada's position on the military use of animals and of the industries of animal exploitation radically different, the monument 
could serve as a testament to a dark period in the country's history - and a reminder to do better by nonhuman animals in future. Nonhuman animals should be recognized for the sacrifices they have made in the past, but only insofar as we recognize the injustice of requiring such sacrifices from them. A monument like the Animals in War Dedication must be self-critical; we must not allow it to fulfill its ideological function of resolving symbolically, which is to say superficially, a deep contradiction at the heart of Canadian settler society. We must, above all, hold the Government of Canada to the standards it implies in the erection of the Dedication. These imply nothing less than a discontinuation of the use of nonhuman animals in war, and a radical reduction if not abolition of the industries of animal exploitation. To use the language of the first section: the Animals in War Dedication is laudable as an exercise in the ethics of public memory - but it points to a species-inclusive morality of public memory.

\section{Conclusion: From Ethics of Public Memory to Morality of Public Memory}

Margalit's notion of an ethics of memory - and the corollary notion of a morality of memory - helped to orient our consideration of existing norms surrounding the public remembrance of nonhuman animals. In strict terms, Margalit's framework proved to be limited. Since nonhuman animals do not fall into the orbit of human nature - what Kant qualifies as the freedom of human reason, and what Margalit qualifies as the radically open moral agency of each human life - it is at best possible on Margalit's account to speak of an ethics, rather than a morality, of public memory concerning nonhuman animals. As such, Canadian settler norms regarding nonhuman animal remembrance are "thick", "tribal" and imply no universally binding duties; indeed, as we saw they are through and through speciesist - both because they hold nonhuman animals in toto at a lower status than human beings, and because only certain species of domesticated nonhuman animal are included in the "tribe". Thus it is conceptually possible, according to existing norms, to pay tribute to certain species of domesticated animal - dogs, horses, even carrier pigeons who participated in Canadian military campaigns - while systematically abusing, exploiting and killing other species for food, fur and other products on an 
industrial scale in a country that boasts some of the least progressive animal welfare regulations among industrialized nations.

I argued however that this conceptual possibility - the speciesism inherent in existing norms of remembrance - is unstable. The ethics of public memory for nonhuman animals as practiced by the Government of Canada, evinced by the notable public gesture of the Animals in War Dedication, gestures beyond itself, in spite of itself, since it a) implicitly recognizes nonhuman animal moral standing and social citizenship and b) is undermined by its own speciesism. Since there is no question of retracting our existing commitment to nonhuman animal commemoration, it is therefore a question of going forward - remembering, for example, the labour and deaths of animals in agriculture and animal husbandry in addition to the sacrifices of military animals. But once we make this commitment, as I have shown, we are on our way to taking seriously the troubling question: what does it mean to honour those whom we use and kill without their consent?

Such public gestures are therefore troubling, but they are to be supported in the interim and seized upon as an opening towards more progressive and consistent public values.

\section{References}

De Waal, F. (2016). Are We Smart Enough to Know How Smart Animals Are? New York and London: W.W. Norton \& Company.

Donaldson, S., \& Kymlicka, W. (2011). Zoopolis: A political Theory of Animal Rights. New York: Oxford University Press.

Faria, C. (2016). Animal ethics goes wild: the problem of wild animal suffering and intervention in nature. http://www.tdx.cat/handle/10803/385919

Fox, M. A. (2006). The Moral Community. In H. Lafollette (Ed.), Ethics in Practice: An Anthology (3rd ed.). Malden, Oxford and Carlton: Blackwell Publishing. 
Frey, R. G., \& Paton, S. W. (2010). Vivisection, Morals and Medicine: An Exchange. In H. Kuhse \& P. Singer (Eds.), Bioethics: An Anthology. Malden, Oxford and Carlton: Blackwell Publishing.

Horta, O. (2014) "The Scope of the Argument from Species Overlap." In Journal of Applied Philosophy, 31, pp.142-54.

Kant, I. (1980). Lectures on Ethics. Indianapolis and Cambridge: Hackett Publishing Company.

Mannino, A. (2015). "Humanitarian Intervention in Nature: Crucial Questions and Probable Answers." Relations: Beyond Anthropocentrism Vol. 3, No 1.

Margalit, A. (2002). The Ethics of Memory. Cambridge and London: Harvard University Press.

Margalit, A. (2007). La Société décente. Paris: Flammarion.

Margalit, A. (2010). On Compromise and Rotten Compromises. Princeton and Oxford: Princeton University Press.

Putnam, H. (2004). Ethics without Ontology. Cambridge and London: Harvard University Press.

Singer, P. (2010). All Animals are Equal. In H. Kuhse \& P. Singer (Eds.), Bioethics: An Anthology. Malden, Oxford and Carlton: Blackwell Publishing.

Singer, P., \& Mason, J. (2006). The Ethics of What We Eat: Why Our Food Choices Matter. Emmaus, PA: Rodale Books.

Taylor, S. (2017). Beasts of Burden: Animal and Disability Liberation. New York and London: The New Press 